\title{
Climatic Factors, Reproductive Success and Population Dynamics in the Montane Vole, MicRotus montanUS
}

\author{
Aelita J. PinTer \\ Department of Biological SCIENCES — UnIVERSITy of NeW OrLEANS \\ New OrLeans
}

\section{$\downarrow$ ObJectives}

Multiannual fluctuations in population density ("cycles") of small rodents are well known (Elton 1942). Numerous hypotheses have been proposed to explain this phenomenon (for reviews see Krebs and Myers 1974, Finerty 1980, Taitt and Krebs 1985). However, none of these hypotheses, alone or in combination, have been able to explain the causality of cycles.

The objectives of this long-term study are to determine whether environmental variables, possibly acting through reproductive responses, contribute to the multiannual fluctuations of the montane vole, Microtus montanus.

\section{$\downarrow \quad$ Methods}

In 1990, Microtus montanus. were livetrapped at two times of the year: the second half of May (spring study period) and mid-July to mid-August (summer study period). Animals were killed as soon as possible after capture. Animals were aged using weight, total length and pelage characteristics. Reproductive organs, the spleen and the adrenal glands were collected from all animals and preserved in Lillie's buffered neutral formalin for further histological study. Flat skins were prepared from all animals.

Population density was estimated on the basis of the trapping success in a permanent grid (established in 1970). The grid consists of 121 stations placed in a square, $5 \mathrm{~m}$ apart, 11 stations $(50 \mathrm{~m})$ on a side. Each station is marked with a stake. Trapping in this grid was performed only during the summer study period. One unbaited Sherman livetrap was set at each station. Additional trapping was carried out in nearby meadows to obtain additional females for litter size determination. In these areas, traps were not set in a regular pattern; rather, they were placed only in locations showing recent vole activity (cuttings, droppings).

During the spring study period, trapping was carried out in a number of sites, all well removed from the permanent grid. The objective of trapping of sites, all well removed from the permanent grid. The objective of trapping during the spring study period was to determine (on the basis of embryo size) the onset of reproduction on a population-wide basis. The reason for not trapping the grid during the spring study period was to leave the site as undisturbed as possible, since the grid is the major source of information on population density. 


\section{ReSUlTS}

The populations of Microtus montanus had crashed in 1989. However, at the onset of the spring 1990 study period, it was immediately apparent that two key factors favorable for a rapid buildup of animal numbers were present: meltoff had occurred unusually early and precipitation had been low in May. Furthermore, the moisture in the preceding winter's snowpack was below average, contributing to the dryness of the early spring.

The onset of reproduction in Microtus montanus is closely linked with the timing of meltoff since the latter is closely correlated with the onset of vegetative growth of grasses. Substances in such grasses have been shown to stimulate reproduction in Microtus montanus in the laboratory as well as in the field (Pinter and Negus 1965, Berger et al. 1981). As expected, all females collected during spring were pregnant. Early onset of reproduction does not, however, automatically guarantee a successful breeding season. If precipitation during the spring is high, the reproductive success of voles is compromised (Merritt 1985, Pinter 1988), leading to an actual decline in animal numbers. In 1990, the combination of a dry spring and an early onset of reproduction held potential for an increase in population density.

During the summer study period it became apparent that spring conditions had, indeed, been conducive to population growth in Microtus montanus. by the end of the summer study period the population had quadrupled as compared with the population density recorded at the same time in 1989. A decrease in predation pressure no doubt contributed to this successful recovery. There had been extensive precipitation during the early summer (June). This, in turn, had resulted in an unusually luxuriant growth of herbaceous vegetation, providing the voles with exceptionally dense cover and an unusual degree of protection from aerial predators. For example, in one of the study areas the grass had an average height of $1.25 \mathrm{~m}(4 \mathrm{ft}$.). The height and density of the vegetation provided such thorough cover that it was extremely difficult to locate stakes that projected $25 \mathrm{~cm}$ above the ground. Furthermore, weasel populations were low in 1990 , apparently reflecting the previous year's crash in their prey population. The relative scarcity of these small carnivores further reduced predation pressure on the voles.
A recovery of $M$. montanus populations was also observed in other parts of Wyoming, demonstrating a geographic synchrony for microtine population dynamics.

There had also been a large population increase of gophers (Thomomys talpoides) and of shrews (Sorex vagrans). There was, however, an interesting difference between the population dynamics of Microtus, Thomomys, and Sorex. Whereas Microtus population increased in both, optimal and marginal habitats, the increase in the populations of Thomomys and Sorex could be observed only in the optimum habitats for these two species.

\section{$\downarrow$ Conclusions}

In 1990, the increase in population density of Microtus montanus.was consistent with my hypothesis (Pinter 1988) that spring population plays a major role in population fluctuations. The importance of climatic factors as contributors to such dynamics is further emphasized by the geographic synchrony exhibited by this phenomenon.

\section{$\downarrow$ ACKNOWLEDGEMENTS}

I gratefully acknowledge the availability of the facilities at the University of Wyoming-National Park Service Research Center without which it would have been difficult to accomplish this work. I am particularly grateful to the Steering Committee of the UW-NPS Research Center for their cognizance of the fact that an understanding of microtine cycles can be gained only from long-term studies.

\section{Literature Cited}

Berger, P. J., N. C. Negus, E. H. Sanders, and P. D. Gardner. 1981. Chemical triggering of reproduction in Microtus montanus. Science (Washington, D. C.) 214:69-70.

Elton, C. S. 1942. Voles, mice and lemmings. Clarendon Press, Oxford, 496 pp. 
Finerty, J. P. 1980. The Population Ecology of Cycles in Small Mammals. Mathematic Theory and Biological Fact. Yale Univ. Press, New Haven. $234 \mathrm{pp}$.

Krebs, C. J., and J. H. Myers. 1974. Population cycles in small mammals. Adv. Ecol. Res. 8:267-399.

Merritt, J. F. 1985. Influence of snowcover on survival of Clethrionomys gapperi inhabiting the Appalachian and Rocky Mountains of North America. Acta Zool. Fenn. 173:73-74.
Pinter, A. J. 1988. Multiannual fluctuations in precipitation and population dynamics of the montane vole, Microtus montanus. Can. J. Zool. 66:2128-2132.

Pinter, A. J., and N. C. Negus. 1965. Effects of nutrition and photoperiod on reproductive physiology of Microtus montanus. Am. J. Physiol. 280:633-638.

Taitt, M. J., and C. J. Krebs. 1985. Population dynamics and cycles. IN Biology of New World Microtus. R. H. Tamarin, ed. Spec. Publ. Amer. Soc. Mammal. 8:567-620. 